\title{
Bioactivity of a water extract of boldus (Peumus boldus Molina) against Spodoptera frugiperda (J.E. Smith) and Helicoverpa zea Boddie (Lepidoptera: Noctuidae)
}

\author{
Gonzalo Silva $^{1 *}$, J. Concepción Rodríguez ${ }^{2}$, Carlos A. Blanco ${ }^{3}$, and Angel Lagunes ${ }^{2}$
}

\begin{abstract}
The insecticidal properties of water-extract of Peumus boldus Molina and its effect on the development cycle and feeding habits of Spodoptera frugiperda J.E. Smith and Helicoverpa zea Boddie were evaluated under laboratory conditions in concentrations of $0.25,0.5,1.0,2.0,4.0$, and $8.0 \%$ (w/w). Spodoptera frugiperda was the most susceptible with $75 \%$ mortality at $7 \mathrm{~d}$ at $8 \% \mathrm{P}$. boldus concentration, while $H$. zea had only $30 \%$ mortality. LC $\mathrm{L}_{50}$ was $2.31 \mathrm{~mL} \mathrm{~kg}^{-1}$ for $S$. frugiperda and $16.05 \mathrm{~mL} \mathrm{~kg}^{-1}$ for $H$. zea. When the extract concentration increased in the diet, larval size and weight, percentage of pupation and number of adults decreased, and the time required to reach those states was greater. Neonate larvae fed primarily on the diet with the lower extract concentration and the control was preferred by more than $50 \%$ of larvae. Inhibition of feeding, growth, weight gain of 3rd instar larvae as well as new biomass production decreased with concentration of the extract.
\end{abstract}

Key words: Fall armyworm, corn earworm, botanical insecticides, nutritional indexes.

\section{INTRODUCTION}

The fall armyworm (Spodoptera frugiperda J.E. Smith) and the corn earworm (Helicoverpa zea Boddie) are two important pests that affect a large quantity of crops, damage both plant foliage and fruits of many crops (AbdElghafar et al., 1993; Prates et al., 2003). To control these pests, farmers mainly use synthetic insecticides of chemical groups such as organophosphates, carbamates, and pyrethroids (Rodríguez and Vendramim, 1996). However, irrational use has resulted in problems like chemical residues in food, biological disequilibrium, intoxication and development of insect resistance (Roel and Vendramim, 2006).

The search for alternative methods includes the use of natural products that are both effective and less environmentally aggressive, such as plant extracts (Roel and Vendramim, 2006). For Lepidoptera, research has focused on the Meliaceae family with species such as Azadirachta indica A. Juss. (Viana et al., 2007), Guarea trichilioides L., Guarea guidonia (L.) Sleumer, Melia azedarach L. (Rodríguez and Vendramim, 1997;

\footnotetext{
${ }^{1}$ Universidad de Concepción, Facultad de Agronomía, Av. Vicente Méndez 595, Chillán, Chile. *Corresponding author (gosilva@udec.cl). ${ }^{2}$ Colegio de Postgraduados, Programa de Entomología y Acarología, Montecillo, México.

${ }^{3}$ United States Department of Agriculture (USDA), Animal and Plant Health Inspection Service, 4700 River Road, Riverdale, Maryland 20737, USA.

Received: 17 January 2013.

Accepted: 5 April 2013.

doi:10.4067/S0718-58392013000200008.
}

De Brito et al., 2004), Trichilia havannensis (Jacq.) (Caballero et al., 2008), and Trichilia pallida Swartz (Roel and Vendramim, 1999; Roel et al., 2000; Roel and Vendramim, 2006). However, in the last few years, there have been studies with plants of other plant families, such as Quassia amara L. (Simaroubaceae) (Mancebo et al., 2000; Souza et al., 2007), Annona cherimola Mill. (Annonaceae) (Álvarez-Colom et al., 2007), and Anacardium occidentale L. (Anacardiaceae) (De Brito et al., 2004). Many of these species have demonstrated great crop protection potential in laboratory, field, and greenhouse, although few are found in countries with temperate or cold climates. Additionally, many of these extracts are obtained with solvents such as hexane, acetone or methanol, instead of water (Dos Santos et al., 2008; Pedreira et al., 2008). As a result, they cannot be elaborated by farmers because their development requires specialized equipment and rigorous security conditions. The main advantage of water extracts is that even small farmers can prepare them, reducing production costs, health risks and dependence on manufactured insecticides (Viana et al., 2007).

Boldo (Peumus boldus Molina, Monimiaceae) is a Chilean native with insecticidal effect on Sitophilus zeamais Motschulsky (Páez et al., 1990; Silva et al., 2003; 2005; 2006; Pérez et al., 2007), Xanthogaleruca luteola Müll. (Chiffelle et al., 2011), and for third instar larva of Spodoptera littoralis Boisduval (Zapata et al., 2006) and fungicidal properties to Penicillum spp., Fusarium spp., Aspergillus niger and A. flavus (Leite de Souza et al., 2005). However, the effect of this plant's extract on $S$. frugiperda and H. zea has never been reported, and thus the objective of the present report was to evaluate 
the biological activity of water extracts of boldo leaves on larva from these species under laboratory conditions.

\section{MATERIALS AND METHODS}

\section{Plant material}

Dehydrated boldo leaves were obtained in the fruit and vegetable market in the city of Texcoco, State of Mexico, Mexico. The taxonomic confirmation was performed according to Vogel et al. (2005). Pérez et al. (2007) demonstrated that this leaves do not lose their insecticidal properties if they are maintained dehydrated and without grinding. The dehydrated foliage was triturated the same day it was used: it was ground with an electric coffee grinder (KSM2-BLK, Braun, Naucalpan, Mexico) and homogenized with a $250 \mu$ sieve (DUAL Manufacturing, Chicago, Illinois, USA).

The extraction was performed following Prates et al. (2003). A total of $10 \mathrm{~g}$ boldo powder was placed $30 \mathrm{~min}$ in $100 \mathrm{~mL}$ distilled water at boiling point and was left to steep for $24 \mathrm{~h}$. Then the solution was filtered with a Whatman nr 10 paper filter and used as the stock solution $(100 \%)$.

\section{Insects and toxicity assays}

Spodoptera frugiperda and H.zea larva were obtained from a colony in the Laboratory of Toxicology of Insecticides of Entomology and Acarology Program, Colegio de Postgraduados en Ciencias Agrícolas, Montecillo Campus, Mexico, maintained in a bioclimatic chamber at $27 \pm 1{ }^{\circ} \mathrm{C}, 70 \pm 5 \% \mathrm{RH}$, and 14:10 h photoperiod.

For the bioassays, 20-mL plastic cups (Envases Cuevas, Ecatepec, Mexico) were used. Ten milliliters of artificial diet (Tobacco Bollworm, Southland Products, Lake Village, Alaska, USA) were mixed with the boldo extract at $0,0.25,0.5,1.0,2.0,4.0$, and $8.0 \%(\mathrm{v} / \mathrm{v})$. The mixture was performed at $40{ }^{\circ} \mathrm{C}$ to avoid degradation of active compounds (Martinez and van Emden, 2001). Once the diet was cooled and solidified, a neonate larva $(<24$ h-old) was placed in each cup, covered with a perforated cover ( $0.5 \mathrm{~cm}$ diameter), with organza fabric set between the cup and cover to provide ventilation. Mortality was evaluated $7 \mathrm{~d}$ after inoculation; larvae were considered dead when they failed to move after being prodded gently with a dissection needle for $15 \mathrm{~s}$. Six boldo concentrations and untreated control were evaluated with 20 replicates and the methodology was repeated five times on different days (100 cups per treatment). To estimate $\mathrm{LC}_{50}$ and $\mathrm{LC}_{90}$, data were subjected to Probit analysis (Finney, 1971) using the SAS PROC PROBIT procedure (SAS Institute, 1998).

\section{Effect on the life cycle}

The effect of the boldo extract on the life cycle of each species was also evaluated in 100 plastic cups $(20 \mathrm{~mL})$ per treatment as described above. Larvae were allowed to feed for $72 \mathrm{~h}$, and every $48 \mathrm{~h}$ five cups were randomly sampled to measure larval weight and length. Once the control larva reached $75 \%$ pupation, the remaining experimental units were divided in 10 replicates of five cups each. In each repetition, percentage of larva that reached pupal stage, their weight, the number that became adults and the time between larva-pupa and pupa-adult stages were determined.

\section{Choice test for first instar larvae}

To evaluate the feeding preference of neonate larvae, a choice test was performed using $5 \mathrm{~cm}$ diameter and 1.5 $\mathrm{cm}$ in height plastic Petri dishes (Industrias Technicare, Atizapan de Zaragoza, State of Mexico, Mexico) (Gore et al., 2005). Plugs of $1.5 \mathrm{~cm}$ diameter and $0.25 \mathrm{~cm}$ height of each of concentration were randomly and equidistantly arranged inside the dishes, which were covered with perforated lids and internally covered with organza fabric for ventilation and $\mathrm{a}<24 \mathrm{~h}$ larva was placed in their center. Larvae feeding preferences were recorded for five consecutive days, after which plugs were dried in oven at $40{ }^{\circ} \mathrm{C}$ for $48 \mathrm{~h}$ to obtain their dry weight, to compare with dry weight of a set of dehydrated plugs not exposed to insects. Each treatment had 10 replicates per insect species and the methodology was repeated five times over time. In each repetition, treatments were randomly arranged inside the dish to avoid interference of external factors like light or temperature.

\section{Choice test for third instar larvae}

For this independent experiment, $2 \mathrm{~mL}$ of diets with each of the seven concentrations were set in each cavity of a 2 $\times 2 \mathrm{~cm}$ plastic ice cube tray. Plastic $9 \mathrm{~cm}$ diameter $\times 3 \mathrm{~cm}$ height Petri dishes with the bottom lined with a piece of moistened Whatman $\mathrm{nr} 10$ filter paper to maintain relative humidity were used with perforated lids on top with organza fabric for gas exchange. Two diet cubes were placed on each Petri dish: one with the corresponding concentration ( 0 control, $0.25,0.5,1.0,2.0,4.0$, or $8.0 \%$ of the extract in the diet) and the other without treatment. Each Petri dish was infested with one third instar larva, which was allowed to feed for $72 \mathrm{~h}$. The remaining diet was dried at $40{ }^{\circ} \mathrm{C}$ for $72 \mathrm{~h}$ to obtain its dry weight, which was compared with the respective dry weight of 20 cubes of diet not exposed to larvae and dehydrated at the beginning of the bio-assay. Each treatment had 20 replicates and the experiment was repeated five times on different days. The weight results were used to calculate the feeding dissuasion index (FDI; Sadek, 2003):

$$
\mathrm{FDI}=((\mathrm{Ic}-\mathrm{It}) /(\mathrm{Ic}+\mathrm{It})) \times 100
$$

and the feeding inhibition index (FII; Raffa and Frazier, 1988):

$$
\mathrm{FII}=((\mathrm{Ic}-\mathrm{It}) / \mathrm{Ic})) \times 100,
$$

where Ic $=$ Ingestion of untreated diet, and It = ingestion of treated diet. 


\section{No choice tests}

This experiment was performed using third instar larva of both insect species, and was performed as previously indicated, but with the difference that a larva in each Petri dish had access to two diet cubes of same treatment. The dry weight results were used to calculate the FII (Raffa and Frazier, 1988), growth inhibition index (GII):

$$
\mathrm{GII}=[(\mathrm{Wc}-\mathrm{Wt}) / \mathrm{Wc}] \times 100
$$

where $\mathrm{Wc}=$ weight $(\mathrm{g})$ of control larva and $\mathrm{Wt}=$ weight (g) of treated larva; relative consumption rate $(\mathrm{RCR})$ :

$$
\mathrm{RCR}=\mathrm{FIL} /(\mathrm{ILW} \times \mathrm{T})
$$

where FIL = feed intake $(\mathrm{g})$ of larva, during the experimental period, ILW = initial larva weight $(\mathrm{g})$ and $\mathrm{T}=$ experimental period (d); larval weight increase rate (WIR):

$$
\mathrm{WIR}=\Delta \mathrm{W} /(\mathrm{ILW} \times \mathrm{T})
$$

where $\Delta \mathrm{W}$ is increase in larval weight during the experimental period, ILW is initial larval weight (g), and $\mathrm{T}$ is experimental period (d) (Farrar et al., 1989), and the consumed feed conversion efficiency (CFE; Waldbauer, 1968).

$$
\mathrm{CFE}=(\mathrm{WIR} / \mathrm{RCR}) \times 100
$$

\section{Experimental design and statistical analysis}

To evaluate the effect of boldo extract on S. frugiperda and $H$. zea, a randomized complete blocks experimental design was used. Data were transformed to $\sqrt{\mathrm{x}}+0.5$ to achieve variance homogeneity, and then an ANOVA ( $\alpha$ $=0.05)$ and a Tukey test $(\mathrm{p} \leq 0.05)$ were performed with the software Statistical Analysis System (SAS Institute, 1998).

\section{RESULTS}

\section{Toxicity}

The highest larval mortality of S. frugiperda (75\%) was obtained with the $8 \%$ concentration, with no significant differences with $2 \%$ and $4 \%$ concentrations that achieved $57.5 \%$ and $67.5 \%$, respectively (Table 1 ). The $\mathrm{LC}_{50}$ and $\mathrm{LC}_{90}$ were 2.31 and $12.72 \mathrm{~mL} \mathrm{~kg}^{-1}$, respectively (Table 1). Helicoverpa zea presented low susceptibility to the water extract of $P$.boldus since the highest concentration resulted in only $30 \%$ mortality (Table 1). Lower concentrations produced $<15 \%$ mortality and did not differ significantly from control. Its low toxicity was even clearer with $\mathrm{LC}_{50}$ and $\mathrm{LC}_{90}, 16.05$ and $82.3 \mathrm{~mL} \mathrm{~kg}^{-1}$, respectively (Table 1).

\section{Effect on the life cycle}

In $S$. frugiperda the mixture of diet with different concentrations of the water extract of $P$. boldus did not affect significantly larval size or weight compared with control (Table 2). However, $8 \%$ concentration resulted in $60 \%$ less pupation, which was significantly lower $(\mathrm{F}=$ $2.9 ; \mathrm{df}=10 ; 24 ; \mathrm{P}=0.0025)$ than the control and the other extract concentrations. However, pupae formed in the $8 \%$ treatment had a similar weight to others treatments. During the pupa-adult stage, it was observed that as the
Table 1. Dose mortality values produced by incorporating Peumus boldus water extract with insect artificial diet used against Spodoptera frugiperda and Helicoverpa zea neonates at $7 \mathrm{~d}$ after inoculation.

\begin{tabular}{lcc}
\hline Concentration $(\%)$ & Spodoptera frugiperda & Helicoverpa zea \\
\hline Control & $0.0 \pm 0.0 \mathrm{c}$ & $0.0 \pm 0.0 \mathrm{~b}$ \\
0.25 & $0.0 \pm 0.0 \mathrm{c}$ & $0.0 \pm 0.0 \mathrm{~b}$ \\
0.50 & $15.2 \pm 5.5 \mathrm{bc}$ & $0.0 \pm 0.0 \mathrm{~b}$ \\
1.00 & $25.3 \pm 8.3 \mathrm{~b}$ & $2.5 \pm 2.5 \mathrm{~b}$ \\
2.00 & $57.5 \pm 4.7 \mathrm{a}$ & $5.0 \pm 3.3 \mathrm{~b}$ \\
4.00 & $67.0 \pm 6.6 \mathrm{a}$ & $12.5 \pm 5.5 \mathrm{~b}$ \\
8.00 & $75.0 \pm 6.5 \mathrm{a}$ & $30.0 \pm 7.2 \mathrm{a}$ \\
\hline $\mathrm{n}^{\dagger}$ & 200 & 200 \\
$\mathrm{~b} \pm \mathrm{SD}^{9}$ & $0.83 \pm 0.2$ & $0.57 \pm 0.29$ \\
$\mathrm{LC}_{50}^{\S}$ & 2.31 & 16.05 \\
$(95 \% \mathrm{LC})^{\&}$ & $(1.81-3.029)$ & $(9.55-55.6)$ \\
$\mathrm{LC}_{90}^{\S}$ & 12.72 & 82.3 \\
$(95 \% \mathrm{LC})^{\&}$ & $(8.27-24.6)$ & $(30.7-1.073)$ \\
$\operatorname{Pr}^{2} \chi^{2 \Phi}$ & 0.0001 & 0.0001 \\
\hline
\end{tabular}

Within the same column, values with the same lower-case letter are not significantly different according to Tukey test $(\mathrm{p} \leq 0.05)$.

Total number of insects treated.

${ }^{9}$ Probit adjustment slope (b) and standard error of slope (ES).

${ }^{8}$ Lethal concentration ( $\mathrm{g}$ boldo $\mathrm{kg}^{-1}$ diet).

${ }^{\star}$ Confidence limits at $95 \%$.

${ }^{\Phi}$ Probability that a log dose-probit line adjusts to a straight line. SE: Standard error.

concentration increased, adult emergence diminished: control, $0.25 \%$ and $0.5 \%$ concentrations presented $100 \%$ of adult emergence, while $2 \%, 4 \%$, and $8 \%$ presented lower emergence values $(\mathrm{F}=7.39 ; \mathrm{df}=10 ; 24 ; \mathrm{P}<0.001)$ with 60\%, 55\%, and 40\% emergence, respectively (Table 2). Finally, the time between one stage and another was also affected since the time to transform larva into pupa increased with higher concentrations $(\mathrm{F}=4.99 ; \mathrm{df}=10 ; 24$; $\mathrm{P}=0.0001$ ): the control lasted $8.6 \mathrm{~d}$ and $8 \%$ concentration took $13 \mathrm{~d}$. During development from pupa into adult, the longest time was $21.4 \mathrm{~d}$ for $8 \%$ concentration, which was higher $(\mathrm{F}=2.98 ; \mathrm{df}=10 ; 24 ; \mathrm{P}=0.0138)$ than the other treatments, which did not present significant differences among themselves.

Helicoverpa zea showed lower larval sizes ( $\mathrm{F}=9.54$; $\mathrm{df}$ $=8 ; 12 ; \mathrm{P}=0.0004)$ when extract concentration in the diet increased. The largest size occurred in the control with $47.6 \mathrm{~mm}$ and the smallest at $8 \%$ concentration with 29.7 $\mathrm{mm}$. Larval weight presented the same tendency, although only $8 \%$ concentration $(0.31 \mathrm{~g})$ showed significant differences with the rest of the treatments (Table 2). Additionally, for all the concentrations greater or equal to $0.5 \%$, the number of larvae that reached pupal stage were significantly less $(\mathrm{F}=2.19 ; \mathrm{df}=8 ; 12 ; \mathrm{P}=0.001)$ than the control and $0.25 \%$. The pupae that developed into adults were not different between control, $0.25 \%$ and $0.5 \%$ concentrations with values of $100 \%, 77.7 \%$, and $66.6 \%$ development respectively; and they had significantly higher development to adults when compared with the remaining treatments $(\mathrm{F}=5.59 ; \mathrm{df}=8 ; 12 ; \mathrm{P}=0.0042)$ distinguishing $8 \%$ with only $11 \%$ pupation. The time for larva-pupa development increased when the P. boldus concentration increased and was lower with the control 
Table 2. Larval size and weight, percent pupation, pupal weight, time between larval and pupal stages and between pupal and adult stages, and percentage of adult emergence of and Spodoptera frugiperda and Helicoverpa zea fed artificial diet mixed with Peumus boldus water extract.

\begin{tabular}{|c|c|c|c|c|c|c|c|c|}
\hline & Concentration & Larval size & Larval weight & Pupation & Pupal weight & $\begin{array}{c}\text { Larva-Pupa } \\
\text { (LP) }^{1} \\
\text { DDI }^{3}\end{array}$ & $\begin{array}{c}\text { Pupa-adult } \\
(\mathrm{PA})^{2} \\
\mathrm{DDI}^{3}\end{array}$ & $\begin{array}{c}\text { Adult } \\
\text { emergence }^{4}\end{array}$ \\
\hline & $\%$ & $\mathrm{~mm}$ & $\mathrm{~g}$ & $\%$ & $\mathrm{~g}$ & & & $\%$ \\
\hline \multirow[t]{7}{*}{ S. frugiperda } & Control & $38.2 \pm 3.60 \mathrm{a}$ & $0.57 \pm 0.03 \mathrm{a}$ & $100 \pm 0.0 \mathrm{a}$ & $0.27 \pm 0.006 \mathrm{a}$ & $8.6 \pm 0.40 \mathrm{c}$ & $18.6 \pm 0.40 b$ & $100 \pm 0.0 \mathrm{a}$ \\
\hline & 0.25 & $34.7 \pm 0.75 a$ & $0.54 \pm 0.02 \mathrm{a}$ & $100 \pm 0.0 \mathrm{a}$ & $0.29 \pm 0.007 \mathrm{a}$ & $9.0 \pm 0.40 \mathrm{c}$ & $19.0 \pm 0.0 \mathrm{~b}$ & $100 \pm 0.0 \mathrm{a}$ \\
\hline & 0.50 & $34.2 \pm 2.30 \mathrm{a}$ & $0.53 \pm 0.10 \mathrm{a}$ & $100 \pm 0.0 \mathrm{a}$ & $0.29 \pm 0.015 a$ & $9.4 \pm 0.0 \mathrm{c}$ & $19.0 \pm 0.0 b$ & $100 \pm 0.0 \mathrm{a}$ \\
\hline & 1.00 & $33.7 \pm 4.20 \mathrm{a}$ & $0.50 \pm 0.11 \mathrm{a}$ & $95 \pm 5.0 \mathrm{a}$ & $0.28 \pm 0.004 a$ & $10.2 \pm 0.48 b c$ & $19.0 \pm 0.0 \mathrm{~b}$ & $80 \pm 9.3 \mathrm{ab}$ \\
\hline & 2.00 & $32.1 \pm 3.70 \mathrm{a}$ & $0.45 \pm 0.18 \mathrm{a}$ & $90 \pm 6.1 \mathrm{a}$ & $0.27 \pm 0.012 \mathrm{a}$ & $11.4 \pm 0.40 \mathrm{ab}$ & $19.4 \pm 0.40 b$ & $60 \pm 6.1 b c$ \\
\hline & 4.00 & $31.2 \pm 6.20 \mathrm{a}$ & $0.39 \pm 0.10 \mathrm{a}$ & $90 \pm 6.1 \mathrm{a}$ & $0.26 \pm 0.016 \mathrm{a}$ & $11.4 \pm 0.40 \mathrm{ab}$ & $19.8 \pm 0.48 b$ & $55 \pm 9.3 c$ \\
\hline & 8.00 & $27.2 \pm 2.60 \mathrm{a}$ & $0.34 \pm 0.03 \mathrm{a}$ & $60 \pm 12.7 b$ & $0.28 \pm 0.006 a$ & $13.0 \pm 1.26 \mathrm{a}$ & $21.4 \pm 0.74 a$ & $40 \pm 10.0 c$ \\
\hline \multirow[t]{7}{*}{ H.zea } & Control & $47.6 \pm 1.34 \mathrm{a}$ & $0.724 \pm 0.04 \mathrm{a}$ & $100 \pm 0.0 \mathrm{a}$ & $0.425 \pm 0.02 \mathrm{a}$ & $19.0 \pm 1.00 \mathrm{~d}$ & $21.7 \pm 0.33 \mathrm{e}$ & $100 \pm 0.0 \mathrm{a}$ \\
\hline & 0.25 & $38.3 \pm 1.64 b$ & $0.719 \pm 0.02 \mathrm{a}$ & $66.7 \pm 13.3 \mathrm{a}$ & $0.395 \pm 0.03 \mathrm{ab}$ & $21.3 \pm 0.66 \mathrm{c}$ & $23.3 \pm 0.66 \mathrm{~d}$ & $77.7 \pm 11.1 \mathrm{ab}$ \\
\hline & 0.50 & $36.6 \pm 2.90 \mathrm{bc}$ & $0.712 \pm 0.02 \mathrm{a}$ & $44.0 \pm 11.0 \mathrm{~b}$ & $0.353 \pm 0.01 \mathrm{ab}$ & $22.6 \pm 0.66 b c$ & $24.6 \pm 7.68 \mathrm{~d}$ & $66.6 \pm 19.2 \mathrm{ab}$ \\
\hline & 1.00 & $33.9 \pm 3.07 \mathrm{~cd}$ & $0.734 \pm 0.08 \mathrm{a}$ & $44.0 \pm 22.0 \mathrm{~b}$ & $0.342 \pm 0.03 \mathrm{ab}$ & $24.0 \pm 0.0 \mathrm{ab}$ & $26.6 \pm 0.0 \mathrm{~cd}$ & $44.4 \pm 11.1 \mathrm{bc}$ \\
\hline & 2.00 & $32.4 \pm 1.21 \mathrm{~cd}$ & $0.687 \pm 0.05 \mathrm{a}$ & $33.0 \pm 19.1 b$ & $0.334 \pm 0.06 \mathrm{ab}$ & $24.6 \pm 0.66 a$ & $26.0 \pm 0.66 b c$ & $44.4 \pm 11.1 b c$ \\
\hline & 4.00 & $30.8 \pm 0.43 \mathrm{~cd}$ & $0.663 \pm 0.09 \mathrm{a}$ & $33.0 \pm 19.1 b$ & $0.352 \pm 0.02 \mathrm{ab}$ & $25.3 \pm 0.66 a$ & $27.3 \pm 0.66 \mathrm{ab}$ & $22.1 \pm 11.1 \mathrm{c}$ \\
\hline & 8.00 & $29.7 \pm 0.86 \mathrm{~d}$ & $0.314 \pm 0.07 b$ & $33.0 \pm 19.1 b$ & $0.287 \pm 0.07 b$ & $26.0 \pm 0.0 \mathrm{a}$ & $28.6 \pm 0.66 a$ & $11.1 \pm 11.1 \mathrm{c}$ \\
\hline
\end{tabular}

Values with the same letter within a column are not significantly different according to Tukey test $(\mathrm{p} \leq 0.05)$.

${ }^{1} \mathrm{LP}$ : Time lapse (d) in which $50 \%$ of the larvae reached pupal stage.

${ }^{2} \mathrm{PA}$ : Time lapse (d) in which $40 \%$ of the pupae reached adult stage.

${ }^{3}$ DDI: Days after infestation.

${ }^{4}$ Was considered as $100 \%$ the number of pupas obtained in each concentration.

\pm Standard error.

(19 d) than with other treatments $(\mathrm{F}=13.67 ; \mathrm{df}=8 ; 12$; $\mathrm{P}<0.0001)$. The longest period $(26 \mathrm{~d})$ occurred at $8 \%$ concentration. This same relation occurred with the time between pupa-adult with the control: $21.7 \mathrm{~d}$ vs. 27.3 and $28.6 \mathrm{~d}$ for $4 \%$ and $8 \%$, respectively (Table 2 ).

\section{Choice tests first instar larva}

Spodoptera frugiperda neonates presented a clear preference toward the control and the treatments with lower extract concentrations. At 24 and $48 \mathrm{~h}$, control had $40 \%$ and $45 \%$ preference, while concentrations between $0.25 \%$ and $4 \%$ diminished as the concentration increased (Table 3). Between 72 and $120 \mathrm{~h}$, the larvae were only found in the control, $0.25 \%$ and $0.5 \%$, and control diet was always the most preferred with the maximum of $60 \%$ at $120 \mathrm{~h}$. After $72 \mathrm{~h}, 1 \%, 2 \%$, and $4 \%$ concentrations were selected by the larvae, while the treatment with $8 \%$ concentration never presented larvae at any of the evaluations. Diet consumption diminished when concentration increased. The lowest consumption $(0.002$ g) was at $8 \%$, significantly smaller $(\mathrm{F}=2.14 ; \mathrm{df}=10 ; 24$; $\mathrm{P}=0.0478$ ) than control that presented the highest value with $0.030 \mathrm{~g}$.

The preference of $H$. zea was also greater when the extract concentration in the diet diminished. The highest preference was observed for the control with $60 \%(\mathrm{~F}=$ 44.82; $\mathrm{df}=6 ; 2 ; \mathrm{P}<0.001)$. Between 48 and $120 \mathrm{~h}$, no larva was detected in concentrations $>1 \%$ (Table 3 ). After $72 \mathrm{~h}$, there no differences were recorded in the preference

Table 3. Presence of Spodoptera frugiperda and Helicoverpa zea neonates and consumption of insect artificial diet mixed with different concentrations of Peumus boldus water extract.

\begin{tabular}{|c|c|c|c|c|c|c|c|}
\hline & Concentration & $24 \mathrm{~h}$ & $48 \mathrm{~h}$ & $72 \mathrm{~h}$ & $96 \mathrm{~h}$ & $120 \mathrm{~h}$ & Diet intake \\
\hline & & & 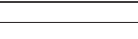 & 6 & & & $\mathrm{~g}$ \\
\hline \multirow[t]{7}{*}{ S. frugiperda } & Control & $40.0 \pm 14.14 \mathrm{a}$ & $45.0 \pm 5.0 \mathrm{a}$ & $50.0 \pm 12.9 \mathrm{a}$ & $55.0 \pm 18.9 \mathrm{a}$ & $60.0 \pm 20.0 \mathrm{a}$ & $0.03 \pm 0.014 \mathrm{a}$ \\
\hline & 0.25 & $20.0 \pm 14.14 \mathrm{a}$ & $25.0 \pm 9.5 \mathrm{ab}$ & $30.0 \pm 5.7 \mathrm{ab}$ & $30.0 \pm 10.0 \mathrm{ab}$ & $30.0 \pm 20.0 \mathrm{ab}$ & $0.03 \pm 0.004 \mathrm{ab}$ \\
\hline & 0.50 & $15.0 \pm 10.00 \mathrm{a}$ & $10.0 \pm 10.0 \mathrm{~b}$ & $20.0 \pm 14.1 \mathrm{ab}$ & $15.0 \pm 9.5 \mathrm{ab}$ & $10.0 \pm 0.0 \mathrm{~b}$ & $0.02 \pm 0.006 \mathrm{abc}$ \\
\hline & 1.00 & $10.0 \pm 5.00 \mathrm{a}$ & $10.0 \pm 5.7 b$ & $0.0 \pm 0.0 \mathrm{~b}$ & $0.0 \pm 0.0 \mathrm{~b}$ & $0.0 \pm 0.0 \mathrm{~b}$ & $0.01 \pm 0.003 \mathrm{abc}$ \\
\hline & 2.00 & $10.0 \pm 10.00 \mathrm{a}$ & $5.0 \pm 5.0 \mathrm{~b}$ & $0.0 \pm 0.0 \mathrm{~b}$ & $0.0 \pm 0.0 \mathrm{~b}$ & $0.0 \pm 0.0 \mathrm{~b}$ & $0.01 \pm 0.004 b c$ \\
\hline & 4.00 & $5.0 \pm 5.00 \mathrm{a}$ & $5.0 \pm 0.0 \mathrm{~b}$ & $0.0 \pm 0.0 \mathrm{~b}$ & $0.0 \pm 0.0 \mathrm{~b}$ & $0.0 \pm 0.0 \mathrm{~b}$ & $0.009 \pm 0.004 b c$ \\
\hline & 8.00 & $0.0 \pm 0.0 \mathrm{a}$ & $0.0 \pm 0.0 \mathrm{~b}$ & $0.0 \pm 0.0 \mathrm{~b}$ & $0.0 \pm 0.0 \mathrm{~b}$ & $0.0 \pm 0.0 \mathrm{~b}$ & $0.002 \pm 0.0008 \mathrm{c}$ \\
\hline \multirow[t]{7}{*}{ H.zea } & Control & $60.0 \pm 11.5 \mathrm{a}$ & $66.7 \pm 6.7 \mathrm{a}$ & $46.67 \pm 13.3 \mathrm{a}$ & $46.67 \pm 13.3 \mathrm{a}$ & $46.67 \pm 13.3 \mathrm{a}$ & $0.042 \pm 0.013 \mathrm{a}$ \\
\hline & 0.25 & $26.6 \pm 6.6 b$ & $26.7 \pm 6.7 b$ & $46.67 \pm 17.6 \mathrm{a}$ & $46.67 \pm 17.6 \mathrm{a}$ & $46.67 \pm 17.6 \mathrm{a}$ & $0.036 \pm 0.005 \mathrm{ab}$ \\
\hline & 0.50 & $6.7 \pm 6.6 c$ & $6.7 \pm 6.7 \mathrm{c}$ & $6.67 \pm 6.7 b$ & $6.67 \pm 6.7 \mathrm{ab}$ & $6.67 \pm 6.7 b$ & $0.036 \pm 0.003 \mathrm{ab}$ \\
\hline & 1.00 & $6.7 \pm 6.6 c$ & $0.0 \pm 0.0 \mathrm{c}$ & $0.0 \pm 0.0 \mathrm{~b}$ & $0.0 \pm 0.0 \mathrm{~b}$ & $0.0 \pm 0.0 \mathrm{~b}$ & $0.009 \pm 0.006 b c$ \\
\hline & 2.00 & $0.0 \pm 0.0 \mathrm{c}$ & $0.0 \pm 0.0 \mathrm{c}$ & $0.0 \pm 0.0 \mathrm{~b}$ & $0.0 \pm 0.0 \mathrm{~b}$ & $0.0 \pm 0.0 \mathrm{~b}$ & $0.003 \pm 0.003 \mathrm{c}$ \\
\hline & 4.00 & $0.0 \pm 0.0 \mathrm{c}$ & $0.0 \pm 0.0 \mathrm{c}$ & $0.0 \pm 0.0 \mathrm{~b}$ & $0.0 \pm 0.0 \mathrm{~b}$ & $0.0 \pm 0.0 \mathrm{~b}$ & $0.002 \pm 0.002 \mathrm{c}$ \\
\hline & 8.00 & $0.0 \pm 0.0 \mathrm{c}$ & $0.0 \pm 0.0 \mathrm{c}$ & $0.0 \pm 0.0 \mathrm{~b}$ & $0.0 \pm 0.0 \mathrm{~b}$ & $0.0 \pm 0.0 \mathrm{~b}$ & $0.001 \pm 0.001 \mathrm{c}$ \\
\hline
\end{tabular}

Within a column, values with the same letter are not significantly different according to Tukey test $(\mathrm{p} \leq 0.05)$.

Diet intake was measured by difference between dry weight before and after consumption by larvae.

\pm SE: Standard error. 
between control, $0.25 \%$ and $0.5 \%$. There were no differences in consumption between control, $0.25 \%$ and $0.5 \%$ concentrations. There were significant differences with the other treatments that fluctuated between $0.009 \mathrm{~g}$ for $1 \%$ and $0.001 \mathrm{~g}$ for $8 \%$.

\section{Choice tests third instar larva}

The FDI and FII in S. frugiperda increased with the extract concentration in the diet (Table 4). For FDI, the minimum

Table 4. Feeding dissuasion index (FDI) and feeding inhibition index (FII) of diet with different concentrations of Peumus boldus water extract incorporated into insect artificial diet against third-instar larvae of Spodoptera frugiperda and Helicoverpa zea.

\begin{tabular}{lccc}
\hline & Concentration & FDI mean \pm SE & FII mean \pm SE \\
\cline { 2 - 4 } S.frugiperda & Control & -- & - \\
& 0.25 & $18.5 \pm 8.6 \mathrm{a}$ & $28.9 \pm 10.8 \mathrm{a}$ \\
& 0.50 & $34.1 \pm 14.3 \mathrm{a}$ & $46.1 \pm 15.4 \mathrm{a}$ \\
& 1.00 & $35.1 \pm 10.3 \mathrm{a}$ & $48.9 \pm 13.3 \mathrm{a}$ \\
& 2.00 & $38.4 \pm 1.3 \mathrm{a}$ & $55.5 \pm 1.4 \mathrm{a}$ \\
& 4.00 & $48.0 \pm 10.4 \mathrm{a}$ & $62.9 \pm 9.5 \mathrm{a}$ \\
& 8.00 & $50.2 \pm 14.3 \mathrm{a}$ & $63.1 \pm 13.5 \mathrm{a}$ \\
\hline H. zea & Control & -- & -- \\
& 0.25 & $16.3 \pm 4.1 \mathrm{~b}$ & $27.4 \pm 5.7 \mathrm{~b}$ \\
& 0.50 & $24.9 \pm 8.0 \mathrm{ab}$ & $37.7 \pm 11.6 \mathrm{ab}$ \\
& 1.00 & $25.4 \pm 10.5 \mathrm{ab}$ & $37.7 \pm 13.9 \mathrm{ab}$ \\
& 2.00 & $25.9 \pm 2.1 \mathrm{ab}$ & $40.5 \pm 2.7 \mathrm{ab}$ \\
& 8.00 & $27.3 \pm 7.8 \mathrm{ab}$ & $41.3 \pm 8.8 \mathrm{ab}$ \\
& $40.3 \pm 3.0 \mathrm{a}$ & $57.3 \pm 3.1 \mathrm{a}$ \\
\hline
\end{tabular}

Within a column, values with the same letter are not significantly different according to Tukey test $(\mathrm{p} \leq 0.05)$.

SE: Standard error.

Feeding inhibition index $($ FDI $)=[$ (intake of non treated feed - intake of treated feed)/(intake of non treated feed + intake of treated feed) $] \times 100$.

Feeding inhibition index $(\mathrm{FII})=[$ (intake of non treated feed - intake of treated feed)/intake of non treated feed) $] \times 100$. inhibition was $18.5 \%$ at $0.25 \%$ concentration and the maximum was $50.2 \%$ with the $8 \%$ concentration. For FII, the minimum value was $28.9 \%$ and the maximum $63.1 \%$ for $0.25 \%$ and $8 \%$ concentrations, respectively. In $H$. zea the lowest FDI was $16.3 \%$ with the $0.25 \%$ treatment, not different from the concentrations $<8 \%$, which had the maximum FDI value of $40.3 \%$. FII had a maximum value of $57.3 \%$ at $8 \%$ concentration, significantly greater for all the remaining concentrations (Table 4).

\section{No choice test}

The highest RCR in S. frugiperda was produced in the control with $0.17 \mathrm{~g} \mathrm{~g}^{-1} \mathrm{~d}^{-1}$ ( $\mathrm{g}$ diet $\mathrm{g}^{-1}$ larva daily) being significantly $(\mathrm{F}=8.26 ; \mathrm{df}=9 ; 27 ; \mathrm{P}<0.0001)$ greater than the rest of the extract concentrations (Table 5). The FII presented direct proportionality with P. boldus concentration, reaching $60.9 \%$ with $8 \%$ extract and the minimum of $14.1 \%$ occurred with the $0.25 \%$ treatment. The $8 \%$ concentration was not significantly different from the concentrations of 2 and $4 \%$, although it was with the lower concentrations $(\mathrm{F}=11.1 ; \mathrm{df}=8 ; 23 ; \mathrm{P}=0.0001)$. The lowest GII occurred at $0.25 \%$ of extract with inhibition of $14.3 \%$, a value that is statistically similar to the value at $0.5 \%$; the highest inhibition was $46.9 \%$ at 4 and $8 \%$ of $P$. boldus although this value was not significantly different from $1 \%(\mathrm{~F}=3.12 ; \mathrm{df}=8 ; 23 ; \mathrm{P}=0.0276)$. The increase in larva weight (WIR) was smaller with higher extract concentrations in the diet: the control presented the highest weight increase of $0.21 \mathrm{~g} \mathrm{~g}^{-1} \mathrm{~d}^{-1}$ being significantly different $(\mathrm{F}=10.98 ; \mathrm{df}=9 ; 27 ; \mathrm{P}=0.0001)$ to all extract concentrations. Finally, CFE was not significantly higher

Table 5. Relative consumption rate (RCR), feeding inhibition index (FIA) and growth (GII), larval weight increase rate (WIR) and consumed feed conversion efficiency (CFE) by third-instar larvae of Spodoptera frugiperda and Helicoverpa zea exposed to artificial diet with different concentrations of Peumus boldus water extract.

\begin{tabular}{|c|c|c|c|c|c|c|}
\hline & Concentration & $\mathrm{RCR}$ mean $\pm \mathrm{SE}$ & FII mean \pm SE & $\mathrm{GII}$ mean $\pm \mathrm{SE}$ & WIR mean \pm SE & $\mathrm{CFE}$ mean $\pm \mathrm{SE}$ \\
\hline & $\%$ & $\mathrm{~g} \mathrm{~g}^{-1} \mathrm{~d}^{-1}$ & 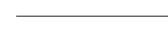 & & $\mathrm{g} \mathrm{g}^{-1} \mathrm{~d}^{-1}$ & $\%$ \\
\hline \multirow[t]{7}{*}{ S. frugiperda } & Control & $0.17 \pm 0.008 \mathrm{a}$ & -- & -- & $0.21 \pm 0.020 \mathrm{a}$ & $90.5 \pm 5.8 \mathrm{a}$ \\
\hline & 0.25 & $0.08 \pm 0.006 b$ & $14.1 \pm 0.29 \mathrm{~d}$ & $14.3 \pm 5.7 \mathrm{c}$ & $0.09 \pm 0.009 b$ & $78.7 \pm 6.8 \mathrm{ab}$ \\
\hline & 0.50 & $0.07 \pm 0.003 b$ & $36.1 \pm 3.15 c$ & $24.4 \pm 3.7 b c$ & $0.07 \pm 0.010 \mathrm{bc}$ & $74.7 \pm 12.3 \mathrm{ab}$ \\
\hline & 1.00 & $0.07 \pm 0.009 b$ & $44.1 \pm 7.60 \mathrm{bc}$ & $32.9 \pm 4.7 \mathrm{abc}$ & $0.06 \pm 0.020 \mathrm{bc}$ & $69.4 \pm 20.2 \mathrm{abc}$ \\
\hline & 2.00 & $0.06 \pm 0.006 b$ & $47.2 \pm 1.10 \mathrm{abc}$ & $41.5 \pm 2.0 \mathrm{ab}$ & $0.04 \pm 0.020 \mathrm{c}$ & $36.3 \pm 20.2 b c$ \\
\hline & 4.00 & $0.06 \pm 0.010 \mathrm{~b}$ & $55.0 \pm 5.50 \mathrm{ab}$ & $46.9 \pm 6.9 a$ & $0.03 \pm 0.010 \mathrm{c}$ & $34.6 \pm 10.3 b c$ \\
\hline & 8.00 & $0.05 \pm 0.010 \mathrm{~b}$ & $60.9 \pm 6.50 \mathrm{a}$ & $46.9 \pm 8.8 \mathrm{a}$ & $0.02 \pm 0.009 \mathrm{c}$ & $28.6 \pm 6.4 c$ \\
\hline \multirow[t]{7}{*}{ H.zea } & Control & $0.128 \pm 0.020 \mathrm{a}$ & -- & -- & $0.11 \pm 0.020 \mathrm{a}$ & $96.0 \pm 20.4 a$ \\
\hline & 0.25 & $0.089 \pm 0.010 \mathrm{ab}$ & $75.3 \pm 5.5 a$ & $7.4 \pm 3.6 b$ & $0.09 \pm 0.020 \mathrm{ab}$ & $90.3 \pm 15.1 \mathrm{a}$ \\
\hline & 0.50 & $0.081 \pm 0.020 \mathrm{ab}$ & $67.4 \pm 12.7 \mathrm{ab}$ & $9.5 \pm 2.7 b$ & $0.05 \pm 0.006 \mathrm{ab}$ & $74.4 \pm 15.3 a$ \\
\hline & 1.00 & $0.076 \pm 0.030 \mathrm{ab}$ & $52.0 \pm 20.7 \mathrm{ab}$ & $15.1 \pm 6.7 b$ & $0.04 \pm 0.004 b$ & $72.0 \pm 28.4 \mathrm{a}$ \\
\hline & 2.00 & $0.056 \pm 0.007 \mathrm{ab}$ & $39.2 \pm 9.2 b$ & $15.5 \pm 3.5 b$ & $0.03 \pm 0.010 \mathrm{~b}$ & $71.4 \pm 28.8 \mathrm{a}$ \\
\hline & 4.00 & $0.053 \pm 0.005 \mathrm{ab}$ & $34.2 \pm 4.2 b$ & $18.7 \pm 3.3 b$ & $0.03 \pm 0.008 b$ & $56.9 \pm 20.3 a$ \\
\hline & 8.00 & $0.039 \pm 0.009 b$ & $33.6 \pm 1.4 b$ & $51.2 \pm 7.6 \mathrm{a}$ & $0.02 \pm 0.009 \mathrm{~b}$ & $49.4 \pm 15.7 \mathrm{a}$ \\
\hline
\end{tabular}

Within a column, values with the same letter are not significantly different according to Tukey test $(\mathrm{p} \leq 0.05)$.

SE: Standard error

$\mathrm{g} \mathrm{g}^{-1} \mathrm{~d}^{-1}=$ diet consumed $(\mathrm{g}) /($ initial larva weight $(\mathrm{g}) \times$ feeding period $(\mathrm{d}))$.

Relative consumption rate $(\mathrm{RCR}) \mathrm{RCR}=\mathrm{IaL} /(\mathrm{PiL} \times \mathrm{T})$, where $\mathrm{IaL}=$ feed intake during the experimental period $(\mathrm{g})$, PiL $=$ initial larva weight $(\mathrm{g})$ and $\mathrm{T}=$ experimental period (d).

Feeding inhibition index (FII) FII = [(intake of non treated feed - intake of treated feed $) /$ intake of non treated feed) $] \times 100$.

Growth inhibition index $(\mathrm{GII}) \mathrm{GII}=((\mathrm{Pc}-\mathrm{Pt}) / \mathrm{Pc}) \times 100$, where $\mathrm{Pc}=$ control larva weight $(\mathrm{g})$ and $\mathrm{Pt}=$ treated larva weight $(\mathrm{g})$.

Larval weight increase rate $(\mathrm{WIR}) \mathrm{WIR}=\Delta \mathrm{P} /(\mathrm{PiL} \times \mathrm{T})$, where $\Delta \mathrm{P}=$ increase in larval weight during the experimental period, $\mathrm{PiL}=$ initial larval weight $(\mathrm{g})$ and $\mathrm{T}$ = experimental period $(\mathrm{d})$.

Consumed feed conversion efficiency $(\mathrm{CFE})=(\mathrm{TIP} / \mathrm{TCR}) \times 100$. 
in the control $(90.5 \%)$ than with the extract concentrations $0.25 \%, 0.5 \%$, and $1 \%$ but it did with the remaining concentrations $(\mathrm{F}=2.49 ; \mathrm{df}=9 ; 27 ; \mathrm{P}=0.0047)$.

The diet consumption (RCR) by $H$. zea diminished as the extract concentration increased. The control presented the highest value of $0.128 \mathrm{~g} \mathrm{~g}^{-1} \mathrm{~d}^{-1}$, different only from the $8 \%$ of extract $\left(0.039 \mathrm{~g} \mathrm{~g}^{-1} \mathrm{~d}^{-1}\right)(\mathrm{F}=2.0 ; \mathrm{df}=9 ; 18 ; \mathrm{P}=$ 0.044 ) (Table 5). Feeding inhibition (FII) increased with $P$. boldus concentration, reaching its maximum inhibitory value of $75.3 \%$ with the $8 \%$ extract. The remaining of the treatments did not surpass $40 \%$. The GII values for extract concentrations between $0.25 \%$ and $4 \%$, there were no significant differences surpassing $20 \%(\mathrm{~F}=6.1$; $\mathrm{df}=8 ; 15$; $\mathrm{P}=0.0003)$, although all were significantly lower than $8 \%$ with $51.2 \%$ inhibition. The same trend was observed in WIR, where the control presented the highest increase in larval weight with $0.11 \mathrm{~g} \mathrm{~g}^{-1} \mathrm{~d}^{-1}$, although it did not differ significantly with treatments of $0.25 \%$ and $0.5 \%$. The lowest increase was recorded for $8 \%$ with $0.02 \mathrm{~g} \mathrm{~g}^{-1}$ $\mathrm{d}^{-1}$, which was statistically different only with the control $(\mathrm{F}=3.65 ; \mathrm{df}=1 ; 18 ; \mathrm{P}=0.003)$. Even when the CFE did not present significantly differences, it was inversely proportion to the extract concentration: the control had $96 \%$ and the $8 \%$ treatment had $49.4 \%$.

\section{DISCUSSION}

The mortality of $S$. frugiperda is lower than the one obtained by Zapata et al. (2006), who mixed artificial diet with $P$. boldus powder at $4 \%$ concentration obtaining mortality $>80 \%$ in S. littoralis larva. In our case the $\mathrm{LC}_{90}$ implied that a $13 \%$ concentration is necessary to obtain $90 \%$ mortality. Additionally, toxicity of water P. boldus extract is similar to that obtained in $S$. frugiperda with other species such as Azadirachta indica (Prates et al., 2003) and higher than found for the extract of Talisia esculenta (A. St.-Hil.) Radlk. (Dos Santos et al., 2008), Sapindus saponaria L. (Dos Santos et al., 2008) and Croton ciliatoglandulifer Ortega (Euphorbiaceae) in $S$. littoralis (Huerta et al., 2002).

Even though there are no previous reports about the toxicity of some derivative of $P$. boldus on $H$. zea, our results indicate that the mortality is lower than the one achieved with other species such as A. indica and Anonna spp., which killed $100 \%$ of larva at $1 \%$ concentration (Grzywacz et al., 2005).

The diminishment in larval and pupal weights, together with the increase in the duration of $S$. frugiperda development cycle at higher $P$. boldus concentrations coincides with the results found with other plant species such as Croton ciliatoglandulifer (Huerta et al., 2002), Ricinus communis L. (Pedreira et al., 2008) and meliaceas of the genus Trichilia spp. (Rodríguez and Vendramim, 1996) and Guarea spp. (Rodríguez and Vendramim, 1997), which indicates that these extracts have growth regulating properties.
In choice test in neonate larvae according to Gore et al. (2005), the spectrum of choice is wider at the beginning due to the period of larval adaption to the environment but finally if the compound has deterrent properties the larvae will be concentrated in lesser concentrations and control.

The FDI values of third instar larvae of S. frugiperda are lower than found by Zapata et al. (2006), who mixed $P$. boldus powder with the diet of S. littoralis in concentrations of $1 \%, 2 \%$, and $4 \%$ obtained values of $60.2 \%, 73.8 \%$, and $96.2 \%$ respectively. In contrast, FII values presented opposite behavior because same authors found that same concentrations did not surpass $22 \%$ with inhibition values below the results found in this study.

In no choice test our FII values are lower than found by Zapata et al. (2006) for S. littoralis larva: $68.9 \%$ and $78.1 \%$ for $2 \%$ and $4 \%$, respectively, and our GII values were also lower than those obtained by these authors: $81.1 \%$ and $86.7 \%$ at concentrations $2 \%$ and $4 \%$.

\section{CONCLUSIONS}

The results obtained for the feeding preference bioassays for both species indicate that a higher extract concentration produces greater feeding inhibition, resulting in lower food consumption and assimilation. The lower production of new biomass results in lower growth and a drop in larval weight. Therefore, Peumus boldus extract presents greater toxicity to Spodoptera frugiperda in comparison with Helicoverpa zea. Even when our results for their effect on the cycle and anti-feeding activity make them valid alternatives for plant protection since their effect on $F_{1}$ will produce an impact of the pest, these results should be validated in the field in order to demonstrate to farmers that they are valid alternatives.

\section{ACKNOWLEDGEMENTS}

The authors thank the technical support of Lauro Hernández Pérez of the Laboratory of Toxicology of Insecticides of Colegio de Postgraduados en Ciencias Agrícolas from México.

\section{LITERATURE CITED}

Abd-Elghafar, S.F., C.O. Knowles, and M.L. Wall. 1993. Pyrethroid resistance in two field strains of Helicoverpa zea (Lepidoptera: Noctuidae). Journal of Economic Entomology 86:1651-1655.

Álvarez-Colom, O., A. Neske, S. Popich, and A. Bardón. 2007. Toxic effects of annonaceous acetogenins from Annona cherimola (Magnoliales: Annonaceae) on Spodoptera frugiperda (Lepidoptera: Noctuidae). Journal of Pest Science 80:63-67.

Caballero, C., J. López-Olguín, F. Ruiz, F. Ortego, and P. Castañera. 2008. Antifeedant activity and effects of terpenoids on detoxication enzymes of the beet armyworm, Spodoptera exigua (Hübner). Spanish Journal of Agricultural Research 6:177-184.

Chiffelle, I., A. Huerta, R. Jiménez, and J.E. Araya. 2011. Proximal analysis and toxicity of extracts from young and mature leaves of boldo tree (Peumus boldus) on elm leaf beetle (Xanthogaleruca luteola). Canadian Journal of Forestry Research 41:2259-2266. 
De Brito, C.H., J.A. Mezzomo, J.L. Batista, M. Barbosa, e A. Murata. 2004. Bioatividade de extratos vegetais aquosos sobre Spodoptera frugiperda em condições de laboratorio. Manejo Integrado de Plagas y Agroecología (Costa Rica) 71:41-45.

Dos Santos, W., M. Freire, P.C. Bogorni, J.D. Vendramim, and M.L. Macedo. 2008. Effect of the aqueous extracts of the seeds of Talisia esculenta and Sapindus saponaria on fall armyworm. Brazilian Archives of Biology and Technology 51:373-383.

Farrar, R., J. Barbour, and G. Kennedy. 1989. Quantifying food consumption and growth in insects. Annals of the Entomological Society of America 82:593-598.

Finney, D. 1971. Probit analysis. 272 p. Cambridge University Press, Cambridge, London, UK.

Gore, J., J. Adamczyk, and C.A. Blanco. 2005. Selective feeding of tobacco budworm and bollworm (Lepidotera: Noctuidade) on meridic diet with different concentrations of Bacillus thuringiensis proteins. Journal of Economic Entomology 98:88-94.

Grzywacz, D., A. Richards, R.J. Rabindra, H. Saxena, and O.P. Rupela. 2005. Efficacy of biopesticides and natural products for Heliothis/Helicoverpa control. p. 371-389. In Sharma, H.C. (ed.) Heliothis/Helicoverpa Management: emerging trends and strategies for future research. Science Publishers, Plymouth, UK.

Huerta, A., J.F. López-Olguín, A. Aragón, P. Del Estal, P. Medina, y E. Viñuela. 2002. Efecto de un pulverizado y un extracto acuoso de Croton ciliatoglanduliferus Ort. (Euphorbiaceae) incorporado a la dieta de Spodoptera littoralis (Boisduval) (Lepidoptera: Noctuidae). Boletín de Sanidad Vegetal. Plagas 28:405-414.

Leite de Souza, E., E. De Oliveira, K.R. De Luna, and C. Paiva de Souza. 2005. Inhibitory action of some essential oils and phytochemicals on the growth of various mould isolated of from foods. Brazilian Archives of Biology and Biotechnology 48:245250 .

Mancebo, F., L. Hilje, A.G. Mora, and R. Salazar. 2000. Antifeedant activity of Quassia amara (Simaroubaceae) extracts on Hypsipyla grandella (Lepidoptera: Pyralidae) larvae. Crop Protection 19:301-305.

Martinez, S., and H. van Emden. 2001. Growth disruption, abnormalities and mortality of Spodoptera littoralis (Boisduval) (Lepidoptera: Noctuidae) caused by azadirachtin. Neotropical Entomology 30:113-125.

Páez, A., A. Lagunes, J.L. Carrillo, y J.C. Rodríguez. 1990. Polvos vegetales y minerales inertes para el combate del gorgojo Sitophilus zeamais (Colepotera: Curculiniodae) en maíz almacenado. Agrociencia 3:35-46.

Pedreira, G., L.E. De Moura, P.R. Ramalho, E.M. Souza, and C.B. Maia. 2008. Efeitos de extratos de plantas na biologia de Spodoptera frugiperda (J.E. Smith, 1797) (Lepidoptera: Noctuidae) mantida em dieta artificial. Ciência e Agrotecnologia 32:792-796

Pérez, F., G. Silva, M. Tapia, y R. Hepp. 2007. Variación anual de las propiedades insecticidas de Peumus boldus sobre Sitophilus zeamais. Pesquisa Agropecuaria Brasileira 42:633-639.

Prates, H., A. Viana, e J.M. Waquil. 2003. Atividade de extrato aquoso de folhas de nim (Azidarachta indica) sobre Spodoptera frugiperda. Pesquisa Agropecuaria Brasileira 38:437-439.
Raffa, K., and J. Frazier. 1988. A generalized model for quantifying behavioral de-sensitization to antifeedants. Entomologia Experimentalis et Applicata 46:93-100.

Rodríguez, C., y J.D. Vendramim. 1996. Toxicidad de extractos acuosos de meliaceae en Spodoptera frugiperda (Lepidoptera: Noctuidae). Manejo Integrado de Plagas 42:14-22.

Rodríguez, C., e J.D. Vendramim. 1997. Avaliação da bioatividade de extratos aquosos de Meliaceae sobre Spodoptera frugiperda (J.E. Smith). Revista de Agricultura 72:305-318.

Roel, A., e J.D. Vendramim. 1999. Desenvolvimento de Spodoptera frugiperda (J.E. Smith) em genotipos de milho tratados com extrato acetato de etila de Trichilia pallida (Swartz). Scientia Agricola 56:581-586.

Roel, A., e J.D. Vendramim. 2006. Efeito residual do extrato acetato de etila de Trichilia pallida Swartz (Meliaceae) para lagartas de diferentes idades de Spodoptera frugiperda (J.E. Smith, 1797) (Lepidoptera: Noctuidae). Ciencia Rural 36:1049-1054.

Roel, A., J.D. Vendramim, R.D. Shiraishi, e N. Frighetto. 2000. Effeito do extrato acetate de etila de Trichilia pallid Swartz (Meliaceae) no desenvolvimento e sobrevivencia da lagarta-docartucho. Bragantia 59:53-58.

Sadek, M. 2003. Antifeedant and toxic activity of Adhatoda vasica leaf extract against Spodoptera littoralis (Lep., Noctuidae). Journal of Applied Entomology 127:396-404.

SAS Institute. 1998. Language guide for personal computer release. 441 p. SAS Institute, Cary, North Carolina, USA.

Silva, G., A. Lagunes, y J.C. Rodríguez. 2003. Control de Sitophilus zeamais (Coleoptera: Curculionidae) con polvos vegetales solos y en mezcla con carbonato de calcio. Ciencia e Investigación Agraria 30:153-160.

Silva, G., O. Orrego, R. Hepp, y M. Tapia. 2005. Búsqueda de plantas con propiedades insecticidas para el control de Sitophilus zeamais Motschulsky en maíz almacenado. Pesquisa Agropecuaria Brasileira 40:11-17.

Silva, G., M. Tapia, R. Hepp, G. Bustos, y F. Osses. 2006. Evaluación de boldo (Peumus boldus Molina) y cal para el control de Sitophilus zeamais Motschulsky. Agrociencia (México) 40:219228.

Souza, M., A. Roel, E.J. Arruda, e A.S. Marques. 2007. Eficiência de produtos vegetais no controle da lagarta-do-cartucho-domilho Spodoptera frugiperda (J.E. Smith, 1797) (Lepidoptera: Noctuidae). Ciência e Agrotecnologia 31:326-331.

Viana, P., H.T. Prates, e P.E. De Aquino. 2007. Efeito de extratos de nim e métodos de aplicação sobre o daño foliar e o desenvolvimento da lagarta-do-cartucho, Spodoptera frugiperda, em milho. Revista Brasileira de Milho e Sorgo 6:17-25.

Vogel, H., I. Razmilic, J. San Martín, U. Doll, y B. González. 2005. Plantas medicinales chilenas. Experiencias de domesticación y cultivo de boldo, matico, bailahuén, canelo, peumo y maqui. 194 p. Editorial Universidad de Talca, Talca, Chile.

Waldbauer, G. 1968. The consumption and utilization of food by insects. Advances in Insect Physiology 5:229-288.

Zapata, N., F. Budia, G. Silva, E. Viñuela, y P. Medina. 2006. Actividad antialimentaria de Maytenus boaria Mol., Peumus boldus Mol. y Quillaja saponaria Mol. sobre Spodoptera littoralis Boisd. Boletín de Sanidad Vegetal. Plagas 32:125-135. 